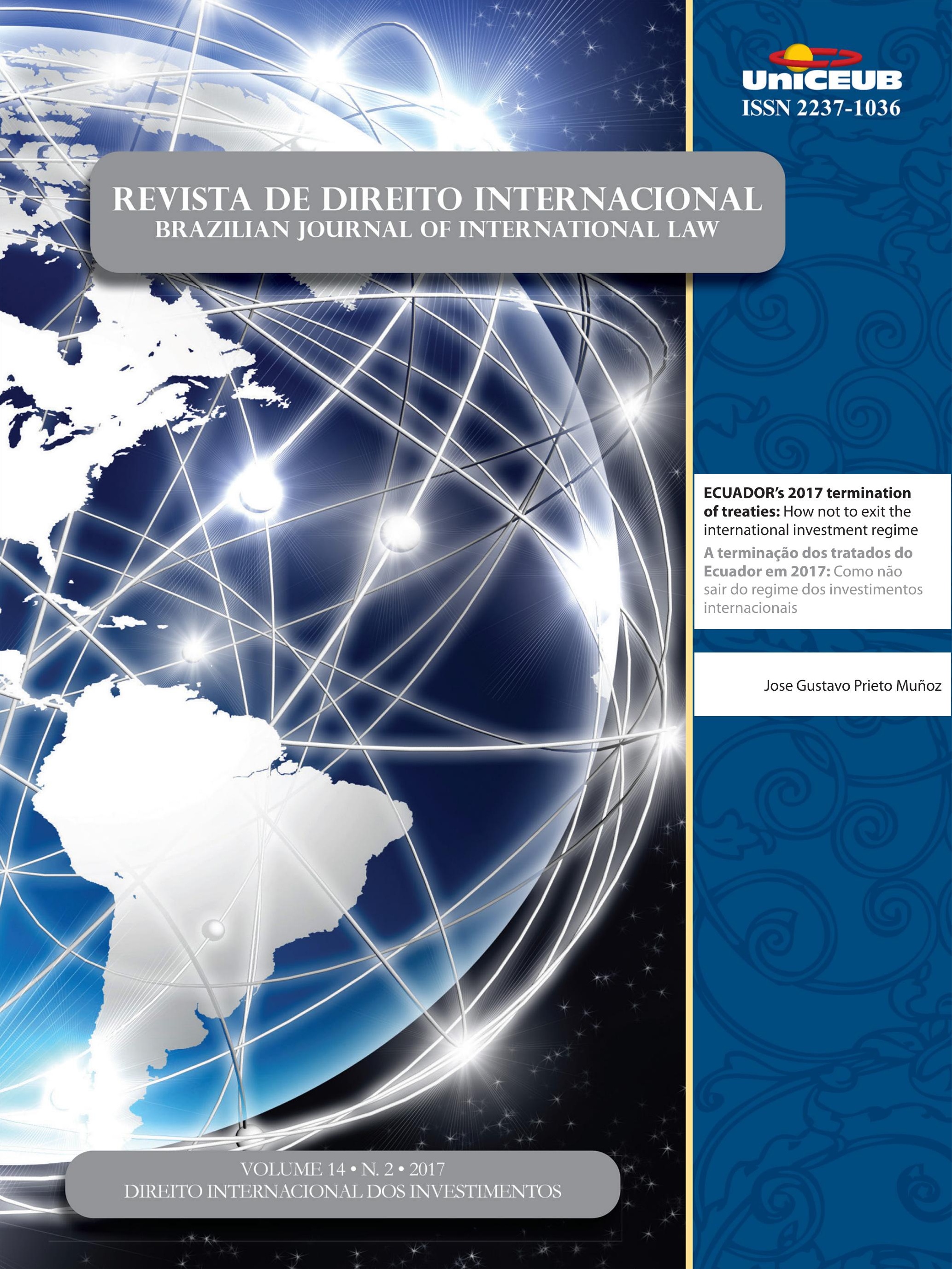




\section{Sumário}

I. Crônicas do Direito Internacional ...............................................1

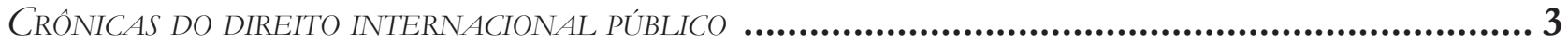

A resolução 2272 (2016) do Conselho de Segurança das Nações Unidas - O POSICIONAMENTO DA ONU FACE ÀS ALEGAÇÕES DE ABUSO E EXPLORAÇÃo SEXUAL POR SUAS

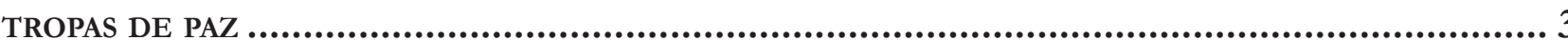

Sarah Dayanna Lacerda Martins Lima

CRÓNICAS DE DiREITo INTERNACIONAL PRIVADO...................................................................

Nadia de Araujo, Marcelo De Nardi, Gustavo Ribeiro, Fabrício Polido e Inez Lopes

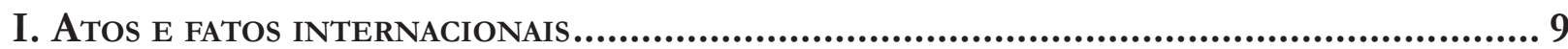

Crônica 1. Novidades de 2017 SObRE CIRCulaÇÃo faCilitada DE SENTENÇAS ESTRANGEIRAS 9

Crônica 2: O Direito Transnacional e os episódios das Carnes.........................................16

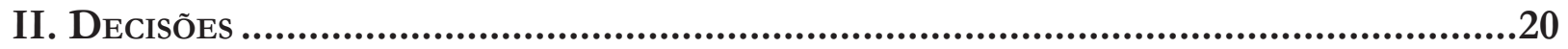

Crônica 3: A Irresistível ForÇa da ORDEM PÚblica E A HOMOLOGaÇÃo DE SENTENÇAS

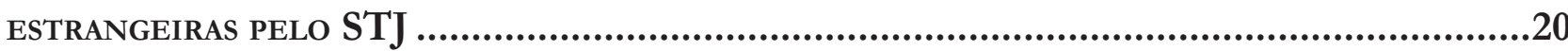

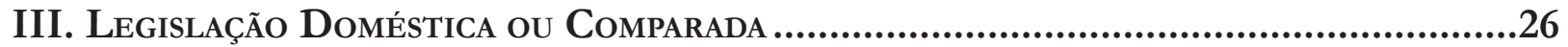

Crônica 4 - Dignidade da pessoa humana e mudança de paradigma da Lei de Migração

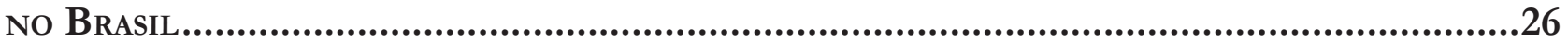

II. Dossiê especial: Direito Internacional dos InVEstimentos ................35

Non-adjudicatory State-State Mechanisms in Investment Dispute Prevention and Dispute Settlement: Joint Interpretations, Filters and Focal Points 
Mapping the Duties of Private Companies in International Investment Law .50 Nitish Monebhurrun

LA LÉGALITÉ DE L'INVESTISSEMENT DEVANT L'ARBITRE INTERNATIONAL: À LA RECHERCHE D'UN POINT D'ÉQUILIBRE .73 Hervé Ascensio

Host STATES AND STATE-STATE INVESTMENT ARBITRATION: STRATEGIES AND CHALlENGES......81 Murilo Otávio Lubamdo de Melo

Right to Regulate, Margin of Appreciation and Proportionality: Current Status in Investment Arbitration in Light of Philip Morris V. Uruguay. .95 Giovanni Zarra

Investments on Disputed Territory: Indispensable Parties and Indispensable Issues....122 Peter Tzeng

The Influence of General Exceptions on the Interpretation of National

Treatment in INTERNATIONAL INVESTMENT LAW. 140 Louis-Marie Chauvel

UMA PRoposta de REFleXão SObRe os ACFIs: Até QUE PONTO O TRATAMENTo de NAÇão MAIS FAVORECIDA PODE MINAR A ESTRATÉGIA POLÍTICA QUE OS EMBASA? 160

Michelle Ratton Sanchez Badin, Daniel Tavela Luis e Mario Alfredo de Oliveira

ECUADOR's 2017 TERMINATION OF TREATIES: HOW NOT TO EXIT THE INTERNATIONAL INVESTMENT REGIME 179

Jose Gustavo Prieto Muñoz

ONE BELT, ONE ROAD: NOVAS INTERFACES ENTRE O COMÉRCIO E OS INVESTIMENTOS INTERNACIONAIS 193

Flávio Marcelo Rodrigues Bruno e Marilda Rosado de Sá Ribeiro

III. Artigos Sobre outros TEMAS..................................................... 214

TolerânCIA E REFugIO: UM ENSAIO A PARTIR Do ACORdo EU-TurQUiA 216 Flávia Cristina Piovesan e Ana Carolina Lopes Olsen 
O TRATAMENTO do APÁtridA NA NOVA LEI DE MIGRAÇÃo: ENTRE AVANÇOS E RETROCESSOS...237 Jahyr-Philippe Bichara

O caráter humanista da Lei de Migrações: aVAnços da Lei N. 13.445/2017 E Os desafios DA REGULAMENTAÇÃO. 254 Marcelo Dias Varella, Clarice G. Oliveira, Mariana S.C. Oliveira e Adriana P. Ligiero

Reform of the United Nations Security Council: The Emperor Has No Clothes.268 Ljubo Runjic

A IDEIA DE QUe os LATINO-AMERICANOS PREFEREM O AUTORITARISMO À DEMOCRACIA À luz da reinterpretação dos Critérios do Programa das Nações Unidas para o DesenVolvimento 286

Gina Marcilio Pompeu e Ana Araújo Ximenes Teixeira

A PRoteção da ORIENTAÇÃo SEXUAL E IDENTIDAdE DE GÊNERO DIVERSAS NA CORTE PENAL internacional: Entre Realpolitiks E Os Direitos Humanos

Gustavo Bussmann Ferreira

A desnacionalização e as violações de direitos humanos na República Dominicana. 331 Daniela Menengoti Gonçalves Ribeiro e Rodrigo Ichikawa Claro Silva

CompetênCia do TPI no Caso do ATAque ao hospital de Kunduz: uma análise ENVOLVENDO A JURISDiÇÃo do TPI EM RELAÇÃO A NACIONAIS DE EsTAdOS NÃO-PARTE do Estatuto DE Roma

Filipe Augusto Silva e Renata Mantovani de Lima

A CRIMINALIZAÇÃo DOS IMIGRANTES EM SITUAÇÃo IRREGULAR NA ITÁliA: BIOPOLÍtica E DIREITO PENAL DO AUTOR.

Maiquel Angelo Dezordi Wermuth e Jeannine Tonetto de Aguiar

The New Rules On Trade And Environment Linkage In Preferential Trade Agreements

Alberto do Amaral Júnior e Alebe Linhares Mesquita

Beyond THE Border between the North and the South: towards a Decolonization of EPISTEMOLOGIES AND FIELDS OF RESEARCH ON MERCOSUR 
A aplicabilidade da Convenção de Montreal no direito brasileiro.

Aziz Tuffi Saliba e Alexandre Rodrigues de Souza

REgIME DE TRANSPARÊNCIA FISCAL NA TRIBUTAÇÃo DOS LUCROS AUFERIDOS NO EXTERIOR (CFC RULES): LACUNAS E CONFLITOS NO DIREITO BRASILEIRO

Paulo Rosenblatt e Rodrigo Torres Pimenta Cabral

As Regras Brasileiras de Tributação de Controladas e Coligadas no Exterior: verdadeiras Controlled Foreign Company (CFC) Rules? .......................................465

Melina de Souza Rocha Lukic e Amanda Almeida Muniz

O RETORNO DE BENS CULTURAIS

Aziz Saliba e Alice Lopes Fabris

Direitos culturais e Nações Unidas: uma análise a partir da Declaração Sobre a eliminação de Todas as Formas de Intolerância e Discriminação Baseadas na Religião OU NA CRENÇA

Leilane Serratine Grubba e Márcio Ricardo Staffen

OS REFLEXOS DA PROTEÇÃO INTERNACIONAL DA PROPRIEDADE INTELECTUAL PARA O DESENVOLVIMENTO INTERNO: UMA ANÁLISE SOBRE O SISTEMA PATENTÁRIO BRASILEIRO E A TRANSFERÊNCIA DE TECNOLOGIA

Michele M. Segala e Isabel Christine S. De Gregori

O CASO HIPOTÉTICO DA MORTE DO EMBAIXADOR FRANCÊS NA ESPANHA: DUAS ESPÉCIES DE IUS gentium em Francisco de Vitoria

Rafael Zelesco Barretto

De volta À BeVilaqua: anÁlise ECONÔMICA dA APLICAÇão do ART. $9^{\circ}$ DA LINDB Às OBRIGAÇÕES CIVIS CONTRATUAIS

Danielle Cristina Lanius e Ivo Teixeira Gico Jr 


\title{
ECUADOR's 2017 termination of treaties: How not to exit the international investment regime*
}

\author{
A terminação dos tratados do Ecuador \\ em 2017: Como não sair do regime dos \\ investimentos internacionais
}

Jose Gustavo Prieto Muñoz**

\begin{abstract}
On 16 May 2017, Ecuador terminated all the 16 Ecuadorian Bilateral Investment Treaties (BITs) still remaining in force. This decision was the end of a longer process that aimed to disengage the South American state from the international investment regime, a process begun nearly a decade earlier, with the drafting of a new constitution in 2008, one that contained an article prohibiting the state from giving consent to investment arbitration. The article argues that it was not the 2017 decision itself, but the different erratic legal steps that led to Ecuador's poor performance in terms of FDI policy. These steps included the initial and unfortunate draft of a constitutional provision, the timing involved in re-evaluating this constitutional decision so many years later, and in general the lack of any pre-established course for action during this process. In this light, the article further claims that an analysis of the Ecuadorian experience can contribute to a better understanding of how the constitutional sphere can best interact with international investment law, potentially by applying specific principles of investment rather than prohibitions on constitutional texts.
\end{abstract}

Keywords: Ecuador, International Investment Law, legitimacy, Latin America.

* Recebido em 25/07/2017

Aprovado em 16/09/2017

** $\mathrm{PhD}$ in Corporate Law and Economics - Doctor Europaeus, University of Verona (Italy). Thanks to the anonymous reviewers for their very valuable comments on an earlier draft of this article. Also, I wish to express my gratitude to the Max Planck Institute for Comparative Public Law and International Law in Heidelberg (Germany), where a substantial part of this chapter was written. Any inaccuracies or errors remain my own. E-mail: jgprietomunoz@gmail.com.

\section{Resumo}

Em 16 de maio de 2017, o Equador terminou todos os seus 16 investimentos bilaterais de investimentos. Esta decisão foi o fim de um processo mais longo que visava desvincular o Estado sul-americano do regime de investimento internacional, um processo iniciado quase uma década antes, com a elaboração de uma nova constituição em 2008, constituição esta que continha um artigo proibindo o Estado de dar consentimento à arbitragem de investimento. O artigo argumenta que não é a própria decisão de 2017 que causou a performance fraca do Equador em termos de investimentos diretos estrangeiro, mas os diferentes passos legais erráticos, incluindo a má elaboração de uma disposição constitucional, o tempo envolvido na reavaliação da decisão constitucional tantos anos mais tarde e, em geral, a falta de um curso de ação pré-estabelecido durante este processo que levou ao mau 
desempenho do Equador em termos de sua política de IDE. Nesta luz, o artigo afirma ainda que uma análise da experiência equatoriana pode contribuir para uma melhor compreensão de como o âmbito constitucional pode interagir melhor com o direito de investimento internacional, potencialmente aplicando princípios específicos de investimento ao invés de proibições sobre textos constitucionais.

Palavras-chave: Equador; legitimidade; direito dos investimentos

\section{INTRODUCTION}

On 16 May 2017, the President of Ecuador signed executive decrees ${ }^{1}$ terminating all of the 16 Ecuadorian Bilateral Investment Treaties (BITs) still remaining in force. This decision was the end of a longer process that aimed to disengage the South American state from the international investment regime, a process begun by the same president nearly a decade earlier, when his political movement moved forward with the drafting and, in 2008, approval of a new constitution that contained an article prohibiting the state from consenting to investment arbitration.

After this constitutional prohibition went into force, the ICSID convention was denounced, and 9 out

1 Presidential Decree No 1399 Denunciation of the Great Britain and Northern Ireland - Ecuador BIT, 16 May 2017; Presidential Decree No 1400 Denunciation of the Federal Republic of Germany -Ecuador BIT, 16 May 2017; Presidential Decree No 1401, Denunciation of People's Republic of China - Ecuador BIT, 16 May 2017; Presidential Decree No 1402, Denunciation of Swiss Confederation - Ecuador BIT, 16 May 2017; Presidential Decree No 1403, Denunciation of Republic of Chile - Ecuador BIT, 16 May 2017; Presidential Decree No 1404, Denunciation of Kingdom of Sweden - Ecuador BIT, 16 May 2017; Presidential Decree No 1405, Denunciation of French Republic - Ecuador BIT, 16 May 2017; Presidential Decree No 1406, Denunciation of Kingdom of the Netherlands - Ecuador BIT, 16 May 2017; Presidential Decree No 1407, Denunciation of Republic of Venezuela - Ecuador BIT, 16 May 2017; Presidential Decree No 1408, Denunciation of Argentine Republic - Ecuador BIT, 16 May 2017; Presidential Decree No 1409, Denunciation of Canada - Ecuador BIT, 16 May 2017; Presidential Decree No 1410, Denunciation of United States of America - Ecuador BIT, 16 May 2017; Presidential Decree No 1411, Denunciation of Kingdom of Spain - Ecuador BIT, 16 May 2017; Presidential Decree No 1412, Denunciation of Republic of Peru - Ecuador BIT, 16 May 2017; Presidential Decree No 1413, Denunciation of Republic of Bolivia - Ecuador BIT, 16 May 2017; Presidential Decree No 1414, Denunciation of Republic of Italian Republic - Ecuador BIT, 16 May 2017. of 26 Ecuadorian 'in force' BITs ${ }^{2}$ were terminated in 2008 while the remaining 17 BITs underwent a tangled process of termination. This process included: different and sometimes contradictory judgements by the Ecuadorian constitutional court regarding the compatibility of BITs with the new constitution; approval processes for the denunciation of the treaties by the legislative branch; the formation in 2013 of a special commission, composed of high officials along with a group of international experts, to audit the international investment law regime; and finally, the termination of the remaining BITs in the year 2017.

Ecuador's decision and the long road taken to terminate the totality of its BITs constitutes a unique case for studying the legitimacy of the international investment regime because Ecuador is one of the few developing countries that has taken the radical decision to terminate all of its connections with the international investment regime. In addition, Ecuador was one of the first countries, along with Venezuela ${ }^{3}$ and Bolivia ${ }^{4}$, to introduce an express constitutional clause to forbid the state from entering into such agreements.

In this context, Ecuador's termination of BITs in 2017 ought to be analyzed not as a new development or resistance to investment arbitration, but rather as the last in a series of chaotic steps that severed the country from the Investment Regime as way to resist to international economic structures, perceived to be 'neoliberal'. In consequence, the steps taken starting from the article inserted in the constitution of 2008 could be one, if not the main cause, of the terrible performance of the Ecuadorian Foreign Direct Investment (FDI) policy in the last years.

The state of Ecuadorian FDI policy is evident now since the country is one of the last destinations for in-

2 Ecuador negotiated 31 known BITs, from those: 1) the 1965 Ecuador - Germany (Bundesrepublik Deutschland) was replaced in 1996 with a new one; 2) the Ecuador- Russia BIT (1996) was never ratified by Russia; 3) The Ecuador-Panama BIT (1996) never entered into force; 4) the Ecuador-Costa Rica BIT (2001) never entered into force; 5) The Ecuador-Egypt BIT according with the information made public by Ecuador was be concluded in 1995 for no renovation of the parties. Therefore, in 2008 Ecuador had only 26 'in force' BITs. See bttp://investmentpolicybub.unctad.org/ILA and CAITISA, "Informe Ejecutivo de la Auditoría Integral Ciudadana de Los Tratados de Protección Recíproca de Inversiones y del Sistema de Arbitraje en Materia de Inversiones en Ecuador," [CAITISIA Report] (Quito, Ecuador 2017), at 15-16.

3 Art 151 of Venezuela's Constitution (1999).

4 Art 366 of Bolivia's Constitution (2007). 
vestment flow in Latin America, it has been one of the most frequently sued states in investment arbitration, and in general has been outperformed by its neighbors ${ }^{5}$ in terms of attracting foreign investment.

On these grounds, I argue here that it was not the 2017 decision itself, but the different erratic legal steps, including the poor drafting of the constitutional provision, the confusing reasons given for a series of constitutional judgements, the timing involved in re-evaluating the constitutional decision so many years later, and in general the lack of a pre-established course of action during this process, that hurt Ecuadorian performance in terms of its FDI policy. In this light, one could also argue that the Ecuadorian experience is a key case study for those studying the interplay between constitutional law and international investment law on the one hand and the alleged constitutionalization of international investment law on the other. I further claim that specific principles of investment should be used rather than prohibitions on constitutional texts.

This analysis proceeds as follows: Section 1 will briefly describe the different legal steps undertaken by Ecuador to effectively disconnect itself from the regime, commenting on the ambiguities of the constitutional provision (2008) and the distinct reasons expressed in the judgments of the Ecuadorian Constitutional Court (2010-2013). Then, Section 2 will focus on the termination of the remaining BITs and the very critical report of the commission created by the executive branch which formed the basis for this decision. This section will analyze how the tone, structure and timing of the report functioned as a curtain to hide the poor performance of Ecuadorian FDI policy over the last decade. Finally, in the last section, I will further argue that we can learn from the Ecuadorian experience that any use of the constitutional sphere to interact with investment arbi-

5 In the last years, the flows of FDI into Ecuador have been considerably less than those for its two neighbors, Colombia and Peru, countries that also share similar economic and social characteristics. In the period 2006 - 2011, the flows of FDI into Ecuador (2,639 USD MM) were about $5 \%$ of FDI in Colombia (55,414 USD MM) and $7 \%$ of FDI in Perú (38,109 USD MM). In the period $2012-$ 2016, the FDI of Ecuador (4,133 USD MM), was about $6 \%$ of FDI in Colombia (72,736 USD MM), and 10\% of FDI in Peru (41,164 USD MM). See the information available in: UNCTAD WIR17 World Investment Report 2017: UNCTAD WIR16 World Investment Report 2016; UNCTAD WIR15 World Investment Report 2015; UNCTAD WIR14 World Investment Report 2014: UNCTAD WIR13 World Investment Report 2013; UNCTAD WIR12 World Investment Report 2012. tration should be based on the insertion of principles of investment rather than rules or prohibitions.

\section{The LONG ROAD OF ECUAdor BIT TERMINATIONS}

\subsection{The Constitutional Assembly and article 422 of the Ecuadorian Constitution}

In 2008, in the town of Montecristi, Ecuador, a constitutional assembly drafted the twentieth Ecuadorian constitution. Article 422 of the new Ecuadorian Constitution, a very extended constitutional text composed of 444 articles, aims to disengage the country from the international investment law regime. The text of the article is the following:

\begin{abstract}
No international treaties or instruments may be concluded where the Ecuadorian State yields its sovereign jurisdiction to international arbitration entities, in disputes involving contracts or of a commercial nature, between the State and natural persons or legal entities.

The treaties and international instruments that provide for the settlement of disputes between States and citizens of Latin America by regional arbitration entities or by jurisdictional organizations designated by the signatory countries are exempt from this prohibition. $[\ldots]^{6}$
\end{abstract}

As pointed out by the Argentinean jurist Gargare1la, the constitutional changes effected in Latin America since the late twentieth century represent a response to two important kinds of historical event: the grave human rights abuses committed by dictatorial governments, and the social crisis which is, in part, a result of the so called 'neoliberal' structural adjustment programs during the 1990s. Taking this into account, article 422 of the Ecuadorian constitution, could also be explained as a reaction to economic governance structures as will be further explained in Section 3.

The drafting of any important legal text and especially the constitution of a country demands special care in order to avoid ambiguities that could obstruct the fulfillment of the very collective choices that should be implemented. This is precisely the case with the text of article 422 of the Ecuadorian constitution, as has

6 Author's translation of Art. 422. 
already been commented on in the literature ${ }^{7}$, because it contains at least three important ambiguities that ought to be noted: About the subject, the object and the temporal effect of the constitutional provision.

The first ambiguity is related to the scope of the prohibition against yielding state sovereignty to international arbitration for disputes of a 'commercial nature' [indole commercial] without directly making use of the word 'investment.' The use of the phrase 'of a commercial nature' implies a different set of economic transactions that are governed by different regimes (i.e. WTO law) on the international level.

The second ambiguity is in the object of the prohibition, since the article makes reference to "No international treaties or instruments may be concluded" [No se podrán celebrar tratados o instrumentos] where it is not clear if the prohibition covers investment "contracts" as well. Once again, regardless of the assessment of the benefits of the measure, the drafters of the constitution could have directly included more specific words such as "contracts" or "investment" in the wording of the article, if their intention was to completely disengage the state from the investment regime.

Finally, a third ambiguity results from the silence throughout the constitutional text on the temporal effect of such strong decisions, since this prohibits the cession of sovereignty, but does not specify the consequences for investment treaties already in force. It is worth noting that the Ecuadorian constitution includes 30 temporal clauses to regulate the transition between the new and old constitutions, but in none of these specifies what should be done with the investment treaties already in force. From the discussions of the constitutional assembly, it appears that the drafters where not even aware exactly what treaties the Ecuadorian state was party to. On this point, it would have sufficed if the Ecuadorian drafters had simply included a text mandating the re-negotiation or termination of valid treaties.

The described ambiguities show that the drafters of the constitution did not envision a clear legal course of action for how the termination process should proceed, beyond specific references to the Occidental (la OXY)

7 For a clear analysis of the text see Katia Fach Gómez, Ecuador's Attainment of the Sumak Kawsay and the Role Assigned to International Arbitration (4 August 2011), available electronically at SSRN: https://ssrn.com/abstract=1904715 or http://dx.doi. org/10.2139/ssrn. 1904715 case lost by Ecuador. This case was the first of two-important arbitral processes between the south American state and the Occidental Exploration and Production Company, a corporation incorporated in the state of California, US. The first Occidental award related to a participation contract with Petroecuador, a State-owned corporation, to undertake exploration and production of oil. The conflict started when the Ecuadorian tax authority (SRI) denied applications for VAT tax refunds and required the return of previous reimbursements ${ }^{8}$. In 2004, an arbitral Tribunal found that Ecuador had breached the national treatment and fair and equitable standards contained in the USA-Ecuador BIT?

The case gained public attention, despite its highly technical nature, because it was believed to be a 'tax matter' that ought to fall within Ecuadorian sovereign competences. For this reason, Ecuador tried to set aside the award in the UK courts and lost its last appeal on March 2007, months before the constitutional process started. The issue was therefore still on the minds of the Ecuadorian drafters ${ }^{10}$.

Besides the mention of this case, the discussions reflected on the transcripts of the Ecuadorian constitutional assembly are remarkable for the absence of any reference to empirical studies that could shed some light on the possible outcomes and impact of the insertion of article 422. Even more, a clear complaint was made by one of the Ecuadorian drafters who strongly denounced the lack of time given to properly study the provision, saying: 'It cannot be analyzed [referring to a group of articles including 422]. If I wanted to talk about all the articles, I would need exactly fifteen secon$\mathrm{ds}$ for each of them and that is impossible ${ }^{11}$. Since, the use of a constitutional text implies long term use and impact, one would have expected a deeper analysis to be conducted when the prohibition was introduced.

8 Occidental Exploration and Production Company v the Republic of Ecuador, (2004), paras 1-6.

9 Ibid para 200.

10 See Ecuador Constitutional Assembly [Asamblea Constituyente Ecuador] Acta 038 Sumario - 22 April 2008; [Asamblea Constituyente Ecuador] Acta 050- A, 16 May 2008.

11 Personal translation of the of the speech pronounced by drafter Diana Acosta, Transcripts of the discussions of article 422, Asamblea Constituyente Ecuador [Ecuador Constitutional Assembly] Act No 050- A -16 May 2008. 


\subsection{The Ecuadorian Constitutional Court Judgements}

Ecuador concluded in 1965 its first BIT with the Federal Republic of Germany ${ }^{12}$ (Bundesrepublik Deutschland), and since then signed at least 30 BITs more and the ICSID convention. When the constitutional assembly drafted article 422 in 2008, with the intention of disengaging the country from the international investment regime, Ecuador was a part of 26 bilateral investment treaties ${ }^{13}$. Since then, the country began the process of the denunciation of nine BITs using the previous constitutional rules (constitution of 1998), which allowed the executive branch to terminate them directly without the consent of the parliament ${ }^{14}$. For the remaining seventeen treaties, the process of termination began using the rules of the new 2008 constitution which mandated that the newly created constitutional court of Ecuador should make a determination as to the compatibility of the international treaties before denunciation.

As one of the first constitutional judges to be confronted with the legitimacy of investment arbitration, the Ecuadorian Constitutional Court had the unique opportunity to shape not only legal discourse in the field, but also to solve the practical problems that arose from the ambiguities of article 422.

However, the outcome was a set of diverse judgments issued by the Ecuadorian court on the same topic. In the period 2010-2013 the court produced a series of decisions regarding the constitutional analysis of each of the remaining BITs in the process of being terminated. Yet, despite the fact that this was the same constitutional court interpreting the same article in regard to the same type of similar investment treaties, the court couldn't produce a uniform line of reasoning for the various judgements and instead used different arguments and even arrived at different conclusions.

First, in 2010, a group of sentences contained a more radical argumentation, where the court not only studied the compatibility of the BIT with the constitution but adopted a defensive stance towards the invest-

\footnotetext{
12 See the text available electronically at http://investmentpolicyhub.unctad.org/

13 See n. ii

14 CAITISA, "Informe Ejecutivo de la Auditoría Integral Ciudadana de los Tratados de Protección Recíproca de Inversiones y del Sistema de Arbitraje en Materia de Inversiones en Ecuador" [CAITISA Report] (Quito, Ecuador 2017), at 24.
}

ment regime. Specifically, on the Ecuador-Great Britain BIT judgement, the Ecuadorian Court appeared to be responding or interacting with a non-determined interlocutor in its judgement, one that apparently claimed that the Ecuadorian system is slow and immoral, but without specifying who had made these claims nor in what context they were made. The words of the court were the following:

\begin{abstract}
"In essence, through these instruments [referring to BITs], the Ecuadorian State has ceded the jurisdiction of national judges in disputes or conflicts, at the international level. It has been argued that our legal system is neither reliable nor suitable, that it is slow and immoral, and it has been argued that external arbitration is the ideal mechanism for resolving conflicts or differences $[\ldots]^{15}$
\end{abstract}

In addition, the court raises various additional ideas in a few sentences regarding the real benefits for Ecuadorian investors included in the BITs, the facts that the country had not negotiated the treaties properly, and that arbitration does not represent collective interest. ${ }^{16}$

Also in 2010, another group of decisions adopted a different, more balanced argumentative approach, by analyzing in a more structured manner whether the whole text of the BITs was compatible with the new constitution. For instance, the France-Ecuador BIT judgement analyses the compatibility of each of the treaty clauses with the new constitution. In this development, the court establishes that all the substantive standards of the treaty are in accordance with the Constitution. Even more, it determines that the Fair and Equitable standard — the most controversial and widely used standard in investment arbitration litigation - is compatible with at least three articles of the new Ecuadorian constitution. ${ }^{17}$ Finally, following this reasoning, the Court determined in the case analyzing the Ecuador- France BIT that only those articles containing the investor-state arbitration clause were contrary to article 422 of the Ecuadorian constitution. The Court further explained that it was necessary to partially denounce the treaties, and even reminded the legislative branch that it was of "vital importance"18 to establish mechanisms for

15 Ecuador - Great Britan BIT, Dictamen No 020-10-Dti-Cc Caso No 0008-10-Ti, (2010), at 25

16 One of the sources used by the Court is the website www. quiendebeaquin.org, see footnote 14 , on ibid. at 24 .

17 It mentions that the FET is compatible with articles: 284.8, 339, 416.12 and 321. See Francia - Ecuador BIT, Dictamen No 031-10-Dti-Cc Caso No 0007-10-Ti, (2010), at 21.

18 See ibid at 27. 
dispute resolution, which must be subject to the common agreement of the contracting parties.

Since neither the Vienna Convention of the law of the treaties, nor the Ecuador - France BIT specified a process for the denunciation of just part of a treaty, the sentence of the Court could have been understood not as a mandate to directly terminate the BIT but rather as a mandate to renegotiate its terms.

Finally, in 2013 the last group of decisions regarding the remaining BITS were drafted and here again there were two types of approaches to article 422 , those that were more critical and those that were more balanced. For instance, in the judgment on the Spain-Ecuador BIT, the court concluded that the investor-state clause was incompatible with the constitution, but also stated as a reason for its decision that arbitral tribunals, without specifying which ones ${ }^{19}$, did not respect tax sovereignty and thus affected the 'national interest ${ }^{20}$, justifying the denunciation of the treaty.

In contrast, in the Argentina - Ecuador BIT judgement, the Ecuadorian court determined that the treaty was incompatible with the new Constitution, but unlike the previous cases did not mention the termination of all the agreements and expressly mandated that the 'public bodies concerned ${ }^{21}$ had to renegotiate the articles that contained the dispute resolution mechanisms.

\subsection{The CAITISA report and the 2017 BIT terminations}

In May 2013, when the last set of decisions of the Ecuadorian constitutional court were being made, the president of Ecuador, issued an executive decree ${ }^{22}$ that constituted the 'Commission for the Integral Citizens Audit of the Treaties for the Protection of Investment and the Investment Arbitration System' CComision para la Auditoría Integral Ciudadana de los Tratados de Protección

19 Probably in reference to the Occidental Exploration and Production Company v the Republic of Ecuador, (2004).

20 España-Ecuador BIT, Dictamen No 010-13-Dti-Cc, Caso No 001011-Ti Corte Constitucional del Ecuador, (2013), at 15.

21 The original Spanish text of the sentence is the following: "En consecuencia, corresponderá a los órganos públicos correspondientes renegociar el contenido declarado incompatible con la Constitución de la República, a fin de que las partes determinen otros mecanismos de solución de las diferencias, acordes con los preceptos constitucionales" Argentina- Ecuador Bit Dictamen No 0003-013-Dti-Cc, Caso No 0009-10-Ti, (2013), at 21.

22 Executive Decree No 1506, President of Ecuador, 6 May 2013, (2013).
Reciproca de Inversiones y del Sistema de Arbitraje en Materia de Inversiones] (CAITISA). This Commission was composed of nine experts (eight international and one Ecuadorian) along with four high officials of the Executive branch representing the Ecuadorian government.

Two hypotheses could explain the formation of CAITISA. The first is that Ecuador's government was not sure if the decisions taken on the BITs were appropriate, simply didn't know what to do with them or was honestly seeking information to re-assess the consequence of distancing itself from the regime.

The second hypothesis is that the Ecuadorian government was convinced that it should disengage from the Regime, but desperately needed additional 'good reasons' to justify its policy choices against this regime, both internally and externally. Put more concretely, Ecuador might have been planning to replicate the strategy it used to reduce its public debt in 2007 and 2008, as stated in the same report of CAITISA ${ }^{23}$, when it created a similar entity to determine that the public debt was 'illegitimate' in order to push bond holders to renegotiate a discount on the debt.

This second hypothesis makes more sense considering that just a few months before creating the CAITISA commission, on October 2012, Ecuador was notified about the award in its second case against Occidental, where it was ordered to pay the biggest sum of money ever paid to any investor to date. ${ }^{24}$ So, while Ecuador was creating CAITISA, it was at the same time starting to litigate the annulment process of the Occidental II award. In this scenario, Ecuador needed 'good reasons' to resist the authority of the different investment arbitration process. 'Good reasons' that could not be found either in the discussions of article 422, nor in the contradictory statements made by the Ecuadorian Constitutional Court regarding the same article.

In May 2017, the CAITISA commission presented its report about the investment regime and it became one of the main reasons included in the recitals of each of the sixteen decrees cited by the Ecuadorian president to justify the termination of the remaining BITS.

This report presents historical information on how Ecuador entered the regime by signing a series of bi-

23 CAITISA Report, supran. xiv, at 12.

24 Occidental Petroleum Corporation, Occidental Exploration and Production Company v The Republic of Ecuador (Icsid Case No. Arb/06/11), (2012). 
lateral investment treaties in the nineties, as well as information on the different cases where the state was a responded state. In addition, it contains a strong critique of the legitimacy and legality of the International Investment Regime. In this regard, the report includes legal, sociological, moral and even utilitarian criticisms of the international investment regime that had appeared in the literature over the preceding years and adapted these to the Ecuadorian experience.

These very critical remarks can be summarized as follows: The BITs signed by Ecuador were poorly or not at all negotiated ${ }^{25}$ and they lacked internal debate prior to their ratification ${ }^{26}$. In addition, the report clai$\mathrm{ms}$ that these treaties introduced a 'biased' adjudication system that has since caused serious economic damage to the country in terms of various awards granted on 'tendentious' and 'unjust ${ }^{27}$ grounds. Finally, the report argues that in any case, these treaties did not fullfil their main function ${ }^{28}$ which was to attract Foreign Direct Investment (FDI) to the host state.

It further argued that the small amounts of FDI that entered the country, not only were inefficient with respect to its development aims ${ }^{29}$ but also had an adverse impact on human rights terms and the environment ${ }^{30}$ With this strong rhetoric, the report justified a series of recommendations, most remarkably that the treaties must be terminated and new more balanced ones should be negotiated. The report does not provide a particular draft model of an Ecuadorian BIT treaty, but it does provide a series of recommendations ${ }^{31}$ to follow for its elaboration, which move in the same direction as the 'New Generation of Investment Policies' developed within the 2015 multilateral framework of UNCTAD ${ }^{32}$.

The report offers concrete historical information concerning the way that the Ecuadorian state had entered into the investment regime, by examining the phase of negotiation and ratification of the different investment treaties made in the nineties. Since it has been a common assumption in the international investment

\footnotetext{
25 CAITISA Report, supra n. xiv, at 15.

26 Ibid at 16-17.

27 Ibid at $50-62$, at 94 .

28 Ibid at 63-65.

29 Ibid at 66-70.

30 Ibid at $71-85$.

31 Ibid at $100-108$.

32 See Investment Policy Framework for Sustainable Develop-
} ment (UNCTAD, 2015). field $^{33}$ that developing countries understood the possible costs of Investment agreements, these findings could shed more light on the truly naive way in which developing countries entered the international investment regime in the nineties

In this sense, the argument made in the report is that the Ecuadorian State did not negotiate, and insufficiently debated the content of the BITS. On the one hand, regarding negotiation, the CAITISA commission affirmed that treaties were not submitted to a process of negotiation 'as such' ${ }^{34}$ since the Ecuadorian officers of the previous governments did not assess the consequences of the treaties. On the other hand, concerning the ratification processes, the report affirms that the treaties did not undergo a proper legislative debate or that this debate did not take place at all. For example, it presents the curious case of seven treaties that were approved on the same day by the Ecuadorian parliament ${ }^{35}$.

Despite the fact that this information illustrates a solid point supporting one of the criticisms of investment arbitration, it is still not clear from the report if this problem, both in the negotiation and ratification processes, was one experienced by Ecuador only with respect to its investment treaties, or if on the contrary, it was something that happened to all of treaties signed by that country during the nineties ${ }^{36}$. This is not a minor concern, because it could help to clarify whether the problem was that those treaties were actually imposed on Ecuador, or rather that the country lacked the technical capacity to assess any type of important agreement, not only those related to investment. Two observations can be further elaborated in this regard.

First, the quality of the consent of the host state touches on one of the pillars of the conceptual framework of international law since the very beginning of the discipline, and that is that 'nations are free, indepen-

33 See Poulsen, Lauge Skovgaard and Aisbett, Emma. "When the Claim Hits: Bilateral Investment Treaties and Bounded Rational Learning”, World Politics, 65 No. 2 (2013).

34 CAITISA Report, supran. xiv, at 15.

35 Ibid. at 17

36 For a broader study on how developing countries often ignored the risks of bilateral investment treaties (BITs) until they themselves became subject to an investment treaty claim see Poulsen, Lauge N. Skovgaard and Aisbett, Emma. "When the Claim Hits: Bilateral Investment Treaties and Bounded Rational Learning", World politics, 65 No. 2 (2013). See also Gus Van Harten, "Five Justifications for Investment Treaties: A Critical Discussion." Trade, Law and Development 2 No 1 (2010) 19-58. 
dent, and equal ${ }^{37}$. These premises allow us to structure a legal system where the legal equality of its actors (states) is reflected in the capacity to possess the same rights and obligations. An argument can be made that this de jure equality might not reflect the de facto asymmetries in specialized information - and the methods for processing that information - that exist between developed and developing countries, especially as treaty matters become ever more complex (e.g. international taxation, finance, etc.)

However, this asymmetry in technical information, is not exclusively a problem for international investment treaties, but rather one of the major challenges to the international legal system as we know it, because it empowers epistemic communities that do not necessarily belong to a nation state, but that are transversal in their formation and can influence the text of international legal rules.

The second observation on the consent argument is the global context of the investment regime. During the nineties when most of these treaties were negotiated, arbitral jurisprudence was in its infancy. The AAPL case $^{38}$, the first known investor arbitration case, was decided in 1990, but it was only in the first decade of this century that its impact was evaluated by the doctrine ${ }^{39}$. The same can be said of the Fair and Equitable Standard of Treatment, since its first use in a process was in the year $2001^{40}$, and it was only after the controversial NAFTA cases that it became one of the 'hot topics' of investment arbitration. From this perspective, it was not only the Ecuadorian negotiators or legislators that did not assess the possible consequences of their treaties; All countries, even developed ones, suffered from this lack of awareness of the regime during the nineties.

Another set of criticisms made in the CAITISA re-

37 Emer Vattel, The Law of Nations or Principles of the Law of Nature Applied to the Conduct and Affairs of Nations and Sovereigns, Le Droit Des Gens ou Principes de la Loi Naturelle (London: Clarke, 1811), at liii.

38 Asian Agricultural Products Ltd (AAPL) v Republic of Sri Lankea, International Centre for the Settlement of Investment Disput ICSID Case No. ARB/87/31990, para 18 .

39 See James Thuo Gathii, "War's Legacy in International Investment Law," International Community Law Review, Martinus Nijhoff Publishers 11 (2009).

40 It is believed that the first use on a process of the standard was in Emilio Agustin Maffezini v. The Kingdom of Spain, see Rudolf Dolzer, "Fair and Equitable Treatment: Today's Contours," Santa Clara Journal of International Law 12 Issue 1 Symposium on the Law and Politics of Foreign Investment (2014), at 10. port addresses a series of substantive points that have been made about the regime over the last few years. For instance, the report analyzes the problems regarding specific provisions of standards of treatment, most remarkably the Fair and Equitable Standard ${ }^{41}$ and explains how arbitrators in some Ecuadorian cases have reached different contradictory conclusions ${ }^{42}$. Also, the report puts special emphasis on the 'double hatting' problem in arbitration $^{43}$, referring to conflicts of interest that can arise when actors play multiple roles within the investment regime. These criticisms, while important, have already been documented ${ }^{44}$ and debated not only by the doctrine but most importantly, they have been debated multilaterally, also by Ecuador, in the different UNCTAD ${ }^{45}$ fora.

\section{The Questions that LIE BENEATH THE CAITISA REPORT AND THE TERMINATION OF BITs IN 2017}

The CAITISA report, notwithstanding the useful information compiled about the historical Ecuadorian experience on the international investment regime that was briefly commented on in the previous section, has an important downside: The time of its release, and some of its methodological choices.

First, the report was released almost ten years after the initial political decision was taken by the Ecuadorian constitutional assembly of Montecristi, about

41 CAITISA Report, supran. xiv, at 18.

42 On this point, the report documented the problem of different tribunals arriving at different conclusions while interpreting the same law (Ley 42), see ibid at 39-40.

43 CAITISA Report, supra n. xiv, at 50-62.

44 For an analysis of legitimacy of contradictory arbitral decisions see for instance S. D. Franck, "The Legitimacy Crisis in Investment Treaty Arbitration: Privatizing Public International Law through Inconsistent Decisions," Fordham Law Review 73, no. 4 (2005).; Stephan Schill, "Enhancing International Investment Law's Legitimacy: Conceptual and Methodological Foundations of a New Public Law Approach," Virginia Journal Of International Law Vol 52 (2011). For an analsis of the 'double hatting' issue in international investment practice see the most recent study of Malcolm Langford, Daniel Behn, Runar Hilleren Lie. "The Revolving Door in International Investment Arbitration.” Journal of International Economic Law Vol 20 (2017) 301-332.

45 UNCTAD United Nations Conference on Trade and Development, "IIA 2013, Issue Note No. 3: Reform of Investor-State Dispute Settlement: in Search of a Roadmap " (2013); "World Investment Report 2012 - UNCTAD,” (United Nations Conference on Trade and Development, UNCTAD, 2012). 
seven years after the first set of Ecuadorian Constitutional Court judgments on the matter, and what seems more intriguing two years after the same commission had concluded its work. In relation to the latter point, the report contains a short statement included in one of the footnotes:

'The Commission completed its work in May 2015, despite this, an update was made on the situation of the investor claims ${ }^{446}$.

This short sentence raises more questions. The first one is that according to this information the CAITISA commission finished its work in 2015, but the report was presented to the public in 2017, two years later. This statement reveals that even when the report was ready, the commission decided to keep the information on its findings away from the public by deciding not to release it for a considerable time.

The reasons for this decision are unclear but, at first glance, a point can be made that the release of the information, and the final decision to terminate the remaining 16 BITs, came months after the EU and Ecuador had ratified the treaty of accession to the Free Trade Agreement (FTA) between Colombia, Peru and the EU.

It could be argued that it would have been more difficult for Ecuador to achieve the ratification of its FTA with the EU, if the BITs with key EU member states -Great Britain, Germany, Sweden, Netherlands, France, Spain and Italy — had been terminated by Ecuador before the EU Parliament decided on the accession of Ecuador to the FTA on December 2016. This also indicates that there is still much to learn from the impact that an Investment treaty might have outside the scope of investment, and more concretely, how investment treaties improve (or not) the political relations between countries, and how they can prepare the ground for deeper commercial agreements.

Second, the report is affected by an important methodological choice used in their investigations; it removed from its inquiry the impact of the decision to disconnect itself from the regime in 2008. With this choice, the report effectively avoids answering the main question that Ecuador needed to ask in the year 2017: What was the impact of the decision to exit the regime, a decision enforced by article 422 in the new constitution and implemented over the last decade?

46 CAITISA Report, supra n. xiv, Footnote 19.
In other words, by the year 2017, Ecuador did not need another legal, sociological and moral assessment of the investment regime and its problems, because the country had already taken the political decision to abandon this regime a decade ago. What the country urgently needed was to know the impact of the decision, rather than why there were 'good reasons' to abandon the regime, in the same way that a patient wants to know from a doctor the results of his/her surgery rather than explanations of why the surgery was needed in the first place.

The report does shed some light on the situation of Foreign Direct Investment (FDI) in Ecuador, since it concludes that FDI arriving in Ecuador is 'reduced' 47 a word that is conservative considering that the same report acknowledges that the flow of capital coming into Ecuador during the period from 2000 to 2013 was only $0.79 \%$ of the total amount of FDI that arrived in Latin America and the Caribbean, placing Ecuador $29^{\text {th }}$ out of the 32 countries in this regard in Latin America ${ }^{48}$.

The situation of Ecuador seems even more alarming if the data released by UNCTAD is considered. From this data, we learn that FDI arriving in Ecuador represents only $0.5 \%$ of the total arriving in South America during the chaotic period of disengagement with the regime (2006 to 2017), a considerably smaller amount than that of its two neighbors ${ }^{49}$, Peru and Colombia, which have greatly outperformed Ecuador's economy in this regard. Along these lines, a legitimate inquiry would rather be how much article 422 , the contradictory judgements of the constitutional court, the denunciation of ICSID and BITS affected the disastrous performance of Ecuador in terms of capital inflows.

Even more, the main fear of those who opposed drafting article 422 was precisely that it would affect the flows of FDI coming to the country. As expressed bluntly by one of the few drafters that strongly opposed article 422:

It would be severe for the country, [...] to isolate us from these [...] mechanisms that exist in the world.

$47 \quad$ Ibid at 63 .

48 Ibid.

49 The Foreign Direct Investment (FDI) of Ecuador represents a range that varies between 6 to $10 \%$ of the FDI of Peru and Colombia during the period 2006 to 2016. See the different data contained in UNCTAD WIR17 World Investment Report 2017: UNCTAD WIR16 World Investment Report 2016; UNCTAD WIR15 World Investment Report 2015; UNCTAD WIR14 World Investment Report 2014: UNCTAD WIR13 World Investment Report 2013; UNCTAD WIR12 World Investment Report 2012. 
It's not WE the ones who are going to change the world pretending that these mechanisms do not exist. People in the world will not care that Ecuador does not want to go into arbitration, what they are going to say is: gentlemen, you do not want to go into arbitration, we do not want to have relationships with you. $[\ldots]^{50}$

The CAITISA report by removing the impact of the new constitution as a key variable of the study of Ecuador's investment policy and flows of FDI missed the opportunity to assess the Ecuadorian experience comprehensively. Any country that is seeking to either reform or exit the investment regime, in a well-informed way, should look beyond the CAITISA report in this regard.

\section{The USE OF THE CONSTItUTIONAL SPHERE IN INTERNATIONAL INVESTMENT ARBITRATION}

The Ecuadorian experience shows the unique nature of international investment law, where an arbitral tribunal not only resolves disputes, but exercises a unique type of public authority ${ }^{51}$ that overlaps with that of the state. Like any authority, it needs to be legitimized in the social field where it is exercised. Under this conception, the process of legitimation implies the ability of the investment arbitration system to generate a 'pull of self-compliance ${ }^{52}$ that occurs when 'good reasons ${ }^{53}$ are given for accepting someone else's authority, whether those reasons are sociological, legal or moral ${ }^{54}$.

These 'good reasons' in the case of international investment arbitration were based on utilitarian grounds that fall between moral and social reasons. This means that countries accepted the insertion of arbitration

50 Personal translation of the speech pronounced by the drafter Pablo Lucio-Paredes, Transcripts of the discussions of article 422, Ecuador Constitutional Assembly [Asamblea Constituyente Ecuador] Acta 038 Sumario - 22 April, 2008

51 See, Armin Bogdandy and Ingo Venzke, In Whose Name? A Public Law Theory of International Adjudication (Oxford University Press 2014).

52 Thomas M. Franck, "The Power of Legitimacy and the Legitimacy of Power: International Law in an Age of Power Disequilibrium," The American Journal of International Law 100, No. 1 (2006), at 20 .

53 Parochialism, Cosmopolitanism, and the Paradigms of International Law, Armin von Bogdandy and Sergio Dellavalle in Mortimer N. S. Sellers, Parocbialism, Cosmopolitanism, and the Foundations of International Law, Asil Studies in International Legal Theory (Cambridge: Cambridge Univ. Press, 2012), at 47.

54 See Richard H. Fallon, Jr. "Legitimacy and the Constitution", Harvard Law Review 118 (2005), 1787-2921. clauses in the first place because they were expecting a benefit, whether it was an increase in investment flows or like many small economies, the promise of development. If investment arbitration stops providing those reasons the pull of self-compliance fades away. In this case, compliance can only be achieved exclusively by coercion, which in investment arbitration means the different processes used to enforce awards.

Unlike many regimes of international law, investment arbitration possesses a well-designed legal structure for enforcing decisions relying on the national law of the different states, the ICSID and New York Conventions. Notwithstanding the efficiency of this enforcement mechanism, a system cannot rely entirely on coercion, which can sooner or later provoke a process of resistance.

The Ecuadorian Constitutional process of Montecristi in 2008 illustrates this point. Once an international regime, such as the investment one, stops generating 'good reasons' for the population of the host state to comply with it, a process of resistance could occur. For that reason, the deeper inquiry not only into the legal text of the Ecuadorian constitution that entered into force in 2008, but also into the reasons expressed during the drafting process of Article 422, were useful. Because this process revealed the real reasons that led to a break with the system, not the ones expressed ten years later.

In the different discussions of article 422 of the Ecuadorian constitution, it is possible to distinguish a three-element discourse used by some of the Ecuadorian drafters to resist international investment arbitration. The first is that investment arbitration is perceived as part and parcel of other categories of international economic governance.

In fact, during the discussions by the Ecuadorian constitutional assembly, there were plenty of examples ${ }^{55}$ that illustrated how in the same arguments references to institutions such as 'ICSID', 'IMF', 'WTO', World Bank' were used interchangeably as if all of them were a single body, system or concept. This is a reminder that the academic lines drawn by legal experts can sometimes fade away in public discourse, and the failures of one pillar of economic governance will 'de facto' affect others.

The second element in the Ecuadorian constitutional discourse is the strong idea of exclusion from the

55 Asamblea Constituyente del Ecuador (2008) Acta no. 038 and Acta No.51. 
systems of globalization and transnationalism by an external "other" (e.g. the elite, multinational corporations', etc.). The perceived exclusion by this "other" whether it was referred to as "the multinationals" or "ICSID" was described in specifically economic terms.

Finally, a third element is the search for a methodological refuge from this 'other' inside the absolute conception of the sovereignty of the nation-state. This means that in the logic of this discourse there is an idea that the absolute power of the state should prevail on economic matters. This three-element discourse can be better illustrated by looking at some of the reasons stated behind the Ecuadorian process of 2008, for example the following lines:

'With regard to international arbitration, a
globalizing order is evident in the world, in the last
decades, where it is said that there are no frontiers,
especially for capital; And, International Law
instead of defending life, the People, the human
being, defends the interests of capital and the
multinationals, that is why instruments such as the
famous ICSID which protects foreign investment,
must be rejected by the people [...] That is why
we must recover; National sovereignty also implies
that we do not submit to this type of arbitration
[referring to international investment arbitration].

However, the experience of Ecuador can also illustrate the difficulties of using the constitutional sphere to disengage from the investment regime, especially when there is no clear course of action planned before the actual decision is taken. This lack of planning cannot be better illustrated that with the conclusions of the CAITISA report that sketch guidelines ${ }^{57}$ for an Ecuadorian model of investment agreement. There is no problem with these ideas of reform, but what is notable is that so many years after the decision, there is still not even a model of a treaty on the part of the Ecuadorians with which to take on any new negotiations.

While it is clear that social discontent can trigger constitutional responses to international economic governance, as has happened not only in Ecuador but also in Venezuela and Bolivia, in these cases, it seems that a more appropriate way to process such reactions is by insertion of principles rather than by rules containing prohibitions as in the Ecuadorian case. There are at least three good reasons why the use of principles re-

56 Personal translation of the intervention of the drafter Geovanny Atarihuana, Transcripts of the discussions of Art. 422 of the Ecuadorian Constitutional Assembly. Acta No.038, 22 April 2008.

57 CAITISA Report, supra n. xiv, at 100-103. presents an advantage.

First, since constitutions are supposed to be designed for the long term, it is easier to use principles to adapt to the needs of different generation's foreign investment policy needs. If a rigid and ambiguous prohibition is inserted as in the case of Ecuador, then it could limit the range of policy choices for future generations, who will have to either find loopholes in the provision, or seek to reform it. For instance, if the ambitious multilateral project of an investment court advances, Ecuador will have to again change its constitution to be a part of it.

In addition, a second reason is that principles could transform social needs into a legal language. This mean that once a principle has been inserted in a constitution it has already transformed a specific social problem into a legal obligation, that can eventually be addressed in a legal process or influence the drafting of a treaty.

In consequence, a third reason is that a constitutional text could be a more powerful tool to influence internal change in a regime. This is because it ismore likely that principles that represent social choices transformed into legal language, will be transported to the international legal sphere, either by influencing the text of new treaties, or by supporting specific legal arguments in a particular arbitration process.

Finally, the Ecuadorian case highlights the important role that Constitutional Judges can have when they interact with the regime. The vast majority of Investment Treaties celebrated during the nineties did not undergo the high levels of constitutional scrutiny at the national level that new treaties during the last five years have received. For that reason, interactions between constitutional judges and arbitrators are a new legal phenomenon worth exploring. In this regard, the Ecuadorian experience illustrates the dual functions that Constitutional judges can serve in this interplay: First, is the obvious internal task of controlling the constitutionality - within the legal framework of the host state- of the specific Investment treaty brought to the Court's consideration. However, a second function is generating legal discourses that could engage investment arbitrators in judicial dialogue. It is as part of this second unexplored function that a constitutional judge gains social legitimacy, as well as the legal standing to define new principles that can be used by arbitrators.

The Ecuadorian Constitutional Court missed the opportunity to exercise this second systemic function, 
because they did not develop a uniform legal discourse, even arriving at different judgments as was pointed out above. One of the reasons for this inconsistency in judgements is that without knowing, the Ecuadorian judges where probably among the first constitutional judges to have the opportunity to interact with the investment regime. However, their experience is valuable for understanding these new kinds of interactions which take place ever more frequently on the global stage

\section{Conclusion}

The International Investment Law regime has been undergoing a process of deep transformation at different levels. There is a consensus on the need to reform the regime, with current debates centering on the best methods for such reform. The termination of investment treaties in Ecuador probably represents the most drastic of these methods, and using the constitutional sphere to effect this termination could have long-term consequences. The Ecuadorian experience demonstrates that establishing a well-informed, pre-defined legal course of action is fundamental before measures of this kind are taken. Also, that the use of the constitutional sphere to effect reform might benefit a country more if it is aimed at the construction of principles to be applied in investment rather than at rules establishing prohibitions of any kind. In any case, whether a country is considering terminating its existing BITs, or is more generally investigating the transformation of the international investment regime, the Ecuadorian experience constitutes one of the few experiments in termination and deserves further study in all its complexity.

\section{References}

CAITISA (Comisión de Auditoría Integral Ciudadana de los Tratados de Protección Recíproca de Inversiones y del Sistema de Arbitraje en Materia de Inversiones en Ecuador), "Informe Ejecutivo de la Auditoría Integral Ciudadana de los Tratados de Protección Recíproca de Inversiones y del Sistema de Arbitraje en Materia de Inversiones en Ecuador” [CAITISA Report] (Ecuador, 2017).

Dolzer R, "Fair and Equitable Treatment: Today's Contours." Santa Clara Journal of International Law 12 Issue 1 Symposium on the Law and Politics of Foreign In- vestment (2014).

Fach Gómez K, Ecuador's Attainment of the Sumak Kawsay and the Role Assigned to International Arbitration (4 August 2011), available electronically at https://ssrn.com/abstract=1904715 or http://dx.doi. org/10.2139/ssrn.1904715.

Franck S D, "The Legitimacy Crisis in Investment Treaty Arbitration: Privatizing Public International Law through Inconsistent Decisions." [n English]. Fordham Law Review 73, no. 4 (Mar 2005) 1521-625.

Franck T M, "The Power of Legitimacy and the Legitimacy of Power: International Law in an Age of Power Disequilibrium." The American Journal of International Law 100, no. 1 (2006) 88-106.

Fallon Jr R H, "Legitimacy and the Constitution", Harvard Law Review 118 (2005) 1787-2921.

Gathii J T, “War's Legacy in International Investment Law" International Community Law Review, Martinus Nijhoff Publishers 11 (2009) 353-86.

Van Harten G, "Five Justifications for Investment Treaties: A Critical Discussion." Trade, Law and Development 2 No 1, 19-58

Langford M, Behn D, Hilleren Lie R. "The Revolving Door in International Investment Arbitration.” Journal of International Economic Law Vol 20 (2017) 301-332.

Poulsen L S and Aisbett E, "When the Claim Hits: Bilateral Investment Treaties and Bounded Rational Learning", World Politics, 65 No 2 (2013).

Schill S, "Enhancing International Investment Law's Legitimacy: Conceptual and Methodological Foundations of a New Public Law Approach" Virginia Journal Of International Law Volume 52 (2011) 57.

Sellers M N S, Parochialism, Cosmopolitanism, and the Foundations of International Law. Asil Studies in International Legal Theory (Cambridge Cambridge Univ. Press, 2012).

UNCTAD, "IIA 2013, Issue Note No. 3: Reform of Investor-State Dispute Settlement: In Search of a Roadmap “, 2013.

UNCTAD, Investment Policy Framework for Sustainable Development (UNCTAD, 2015)

UNCTAD, World Investment Report- 2012 (UNCTAD, 2012). 
_ _ World Investment Report- 2014 (UNCTAD, 2014).

_ _ World Investment Report- 2015 (UNCTAD, 2015).

_ _ World Investment Report- 2016 (UNCTAD, 2016).

_ _ World Investment Report- 2017 (UNCTAD, 2017).

Vattel E, The Law of Nations or Principles of the Law of Nature Applied to the Conduct and Affairs of Nations and Sovereigns. Le Droit Des Gens Ou Principes de la loi Naturelle Engl, (London Clarke, 1811).

Asian Agricultural Products Ltd (AAPL) v Republic of Sri Lanka, International Centre for the Settlement of Investment Disput ICSID Case No. ARB/87/31990

Argentina- Ecuador BIT Dictamen No 0003-013-Dti-Cc, Caso No 0009-10-Ti, Corte Constitucional del Ecuador (2013).

Constitution of Venezuela (Constitucion Republica Bolivariana de Venezuela 1999).

Contitucion of Bolivia (Constitución Política del Estado Plurinacional de Bolivia 2007).

Constitución of Ecuador (Constitución de la Republica del Ecuador 2008).

Ecuadorian Constitutional Assembly Acts (Ecuador, 2008), Act No 038, 22 April 2008

_ Act No 050- A,16 May 2008

Ecuador - Great Britan BIT, Dictamen No 020-10-Dti-Cc, Caso No 0008-10-Ti, Corte Constitucional del Ecuador (2010).

España - Ecuador Bit, Dictamen No 010-13-Dti-Cc (Corte Constitucional del Ecuador Caso, No 0010-11-Ti) (2013).

Executive Decree No 1506, President of Ecuador Republic, 6 May, 2013 (2013).

Francia - Ecuador Bit, Dictamen No 031-10-Dti-Cc (Corte Constitucional del Ecuador Caso N.O 0007-10-Ti) (2010).

Occidental Exploration and Production Company v The Republic of Ecuador (2004).

Occidental Petroleum Corporation, Occidental Exploration and Production Company v The Republic of Ecuador (Icsid Case No. Arb/06/11) (2012).

Presidential Decree No 1399 Denunciation of the Great Britain and Northern Ireland - Ecuador BIT, 16 May 2017 (Ecuador, 2017).
Presidential Decree No 1400 Denunciation of the Federal Republic of Germany -Ecuador BIT, 16 May 2017 (Ecuador, 2017).

Presidential Decree No 1401, Denunciation of People's Republic of China - Ecuador BIT, 16 May 2017(Ecuador, 2017).

Presidential Decree No 1402, Denunciation of Swiss Confederation - Ecuador BIT, 16 May 2017 (Ecuador, 2017).

Presidential Decree No 1403, Denunciation of Republic of Chile - Ecuador BIT, 16 May 2017 (Ecuador, 2017).

Presidential Decree No 1404, Denunciation of Kingdom of Sweden - Ecuador BIT, 16 May 2017 (Ecuador, 2017).

Presidential Decree No 1405, Denunciation of French Republic - Ecuador BIT, 16 May 2017 (Ecuador, 2017).

Presidential Decree No 1406, Denunciation of Kingdom of the Netherlands - Ecuador BIT, 16 May 2017 (Ecuador, 2017).

Presidential Decree No 1407, Denunciation of Republic of Venezuela - Ecuador BIT, 16 May 2017 (Ecuador, 2017).

Presidential Decree No 1408, Denunciation of Argentine Republic - Ecuador BIT, 16 May 2017 (Ecuador, 2017).

Presidential Decree No 1409, Denunciation of Canada - Ecuador BIT, 16 May 2017 (Ecuador, 2017).

Presidential Decree No 1410, Denunciation of United States of America - Ecuador BIT, 16 May 2017 (Ecuador, 2017).

Presidential Decree No 1411, Denunciation of Kingdom of Spain - Ecuador BIT, 16 May 2017 (Ecuador, 2017).

Presidential Decree No 1412, Denunciation of Republic of Peru - Ecuador BIT, 16 May 2017 (Ecuador, 2017).

Presidential Decree No 1413, Denunciation of Republic of Bolivia - Ecuador BIT, 16 May 2017 (Ecuador, 2017).

Presidential Decree No 1414, Denunciation of Republic of Italian Republic - Ecuador BIT, 16 May 2017 (Ecuador, 2017). 
Para publicar na Revista de Direito Internacional, acesse o endereço eletrônico www.rdi.uniceub.br ou www.brazilianjournal.org.

Observe as normas de publicação, para facilitar e agilizar o trabalho de edição. 